\title{
The Increasing of Student's Mathematics Critical Thinking Ability Through Problem Based Learning
}

\author{
Yunita Sari \\ Mathematics Education, \\ Postgraduate Program \\ Universitas Negeri Medan \\ Medan, Indonesia \\ yunitasys44@gmail.com
}

\author{
Edy Surya \\ Mathematics Education, \\ Postgraduate Program \\ Universitas Negeri Medan \\ Medan, Indonesia
}

\author{
Asmin \\ Mathematics Education, \\ Postgraduate Program \\ Universitas Negeri Medan \\ Medan, Indonesia
}

\begin{abstract}
Critical thinking is a part of higher order thinking ability that require students to develop the process of analyzing or evaluating information on a problem based on logical thinking to determine decissions. But the fact in learning mathemathics, this ability is still not developed well, so that the aplication of problem based learning is expected to be a solution to increase student's mathematics critical thinking ability. The purpose of this study is to identity the increasing of students' mathematics critical thinking ability as an impact of problem based learning approach. This study was an quasi experimental research. The population of this research is all students in Junior High School of Dwitunggal Tanjung Morawa. The students in VII-1 is choosen as the experimental class and students in VII-2 is choosen as the control class by purposive sampling technique. The data in this study were analyzed using Two Ways ANOVA. The result of this research are the increasing of student's mathematics critical thinking ability using problem based learning is higher than regular learning and there is no interaction between mathematics prerequsite ability and learning on student's mathematics critical thinking ability.
\end{abstract}

Keywords—mathematics critical thinking ability, problem based learning.

\section{INTRODUCTION}

Critical thinking is a form of thinking that needs to be developed in every student. Syahbana [1] revealed that critical thinking is very necessary for the lifes of students so that they are able to filter information, choose whether or not a need is appropriate, question the truth that is sometimes wrapped in lies, and all things that could have endangered their lives. Purnamasari, Pramudya, and Kurniawati [2] also stated that critical thinking patterns need to be developed in the Indonesian education system so that students are able to practice formulating and evaluating their own opinions.

In the current information age, critical thinking ability become abilities that are needed so that students are able to face changing circumstances or challenges in life that is always developing [3]. The mathematics critical thinking ability is very important in preparing students to meet the demands of technological development and the challenges of an increasingly advanced world life with information that is very fast. In improving critical thinking ability, students are expected to be able to try to provide reasonable reasoning in understanding and making complex choices, understanding the interconnection between systems. Students are also expected to be able to use their abilities to try to solve the problems they face independently or in groups and be able to compile, express, analyze and solve problems.

Based on the explanation above, it is clear that critical thinking ability is very important to be mastered by students. But in reality, the activities and learning atmosphere of students in the learning process of mathematics still tend to be passive, monotonous, unattractive and learning activities are centered on the things that are done by the teacher (teacher centered). The tendency of teaching a number of mathematical concepts are interrelated according to patterns that are arranged in a standard manner in the process of learning mathematics. Student activities focus on the activities of the teacher so that the potential abilities of students themselves are not built up. Mathematical learning activities of students focus on learning activities related to work on regular routine questions so that they do not touch aspects of developing thinking ability.

Karim [4] found that most students tend not to play an active role in the learning process because the learning process is still centralized in the teacher and there are no challenging activities so that it can motivate students to be interested in learning mathematics and form critical thinking ability. Wasriono, Syahputra and Surya [5] also revealed that teachers tend to use expository methods in the form of lectures, give examples and practice questions so that they will limit the ability of students to think in finding concepts, as well as using procedures required by students to solve problems.

The fact that the mathematics learning process that has taken place so far ignores the steps of increasing students' mathematical critical thinking abilities. In line with Syahbana's opinion [1], which states that critical thinking habits have not been predetermined in schools, it encourages students to give correct answers rather than encouraging them to come up with new ideas or rethink existing conclusions. The tendency of the mathematics learning process that has taken place so far is lacking in interest and concern. Problems in the mathematics learning process of students show that students' mathematical critical thinking abilities are still low and students are not able to answer problems based on the 
concept information of a topic related contextually to everyday life. In general, students do not have the initiative to find and find out more information that supports the concept of the topic being studied.

One of the lessons expected to increase students' mathematics critical thinking ability is problem-based learning. This is in line with the opinion of Fristiadi and Bharata [6] that the problem based learning model can help pro-active students so that spurred to use and develop students' critical thinking ability. Sunaryo [7] also has an opinion that problem based learning models provide more oppurtunities for students to optimize critical and cretive thinking ability than direct learning models.

In problem based learning students are directed to explore, inquiry, discover and solve problems. The application of this learning model is strived to develop the students' mathematics critical thinking starting to work from a given problem, linking the problem to be investigated by reviewing the problem from many aspects, conducting authentic investigations to find real solutions to real problems, making products in the form of reports for demonstrated to other friends, cooperating with each other to develop social skills and thinking skills.

Mathematics is a science that has rules, namely understanding new material that has mastery requirements before. A topic can only be learned when the hierarchy of the prerequisites has been learned. Therefore, the mathematics prerequisite ability possessed by students will contribute in predicting the success of students' subsequent learning. Students' mathematics prerequisite ability are included in students' internal factors. However, students' mathematics prerequisite ability are not permanent, and are influenced by other internal factors such as factors of interest in learning and concentration of student learning. So it can be predicted that students who have high mathematics prerequisite ability will not fully succeed in the learning process, if the student's interest and concentration factors are disturbed or unfocused. Student internal factors such as students' mathematics prerequisite ability (KAM) may have no effect in the learning process if external factors such as environmental factors, families to the treatment of learning (in this case the provision of learning models) are given different.

Based on the background description of the problem above it is suspected that problem-based learning can be one way to increasing students' mathematics critical thinking ability. For this reason, this study aims to determine whether the increase in mathematics critical thinking ability of students who taught using problem-based learning is higher than students who taught using regular learning and find out whether there is an interaction between learning and students' prerequisite mathematics ability towards increasing mathematics critical thinking ability.

\section{METHOD}

This type of research used in this study is a quasi experiment that aims to determine the increasing of mathematics critical thinking ability of students through problem-based learning. This research was carried out at Junior High School of Dwitunggal Tanjung Morawa, located in Tanjung Morawa Sub-District, Deli Serdang Regency in the academic year 2019/2020.

The population of this study was all students in Junior High School of Dwitunggal Tanjung Morawa while the sample of the study was grade VII by taking a sample from two classes which consisting of 33 students in class VII-1 as an experimental class and 33 students in the class VII-2 as a control class.

The independent variables in this study are problem-based learning and regular learning, while the dependent variable is mathematics critical thinking ability of students and control variables namely the prerequsite mathematics ability of students in groups (high, medium, low).

The research design used in this study was the pretestposttest control group design. The instruments used to obtain data in this study were the prerequisite mathematics ability test and the mathematics critical thinking ability test assessed by competent validators including mathematics lecturers and mathematics teachers and were tested on respondents outside the study sample. The data in this study consisted of testing for normality, testing for homogeneity, testing for average differences, calculating the gain index, and testing for hypotheses. Testing all statistical hypotheses in this study using two-ways ANAVA.

\section{RESULT AND DISCUSSION}

\section{A. Result}

Before learning is done, students in both classes are given KAM test to find out the prerequisite mathematics abilty of students learning outcomes. A description of students' mathematics prerequisite abilitydata for both classes is showen in table 1.

TABLE I. DESCRIPTION KAM TEST

\begin{tabular}{|c|c|c|c|c|c|}
\hline Sample & N & Sum & Mean & SD & Variance \\
\hline Experiment & 33 & 2669 & 80,88 & 4,519 & 20,422 \\
\hline Control & 33 & 2638 & 79,94 & 3,992 & 15,934 \\
\hline
\end{tabular}

The average KAM score for each class of research samples was relatively the same, in the experimental class was 80,88 and in the control class was 79,94. To find out the equality of the KAM scores in the research sample class, it was done by an analytical test covering normality and homogeneity. It was found that the significance value of Kolmogorov-Smirnov for the experimental class was 0,073 and the control class 0,094. The both significant value is greater than significant level value 0,05 , so that the data are normally distributed for the experimental and control classes. The homogeneity calculation results show that a significant value of 0,377 is greater than significant level 0,05 so that both samples have homogeneous data variance. 
By using $t$ test at the significant level 0,05 obtained $t_{\text {count }}$ 0,895 of the significant 0,374 while the $t_{\text {table }} 1,67$. Because $t_{\text {count }}<t_{\text {table }}(0,895<1,67)$ and significant $>0,05$ $(0,374>0,05)$, it can be concluded that there is no difference in the average ability between the experimental and the control group. So both groups have the same mathematics prerequisite ability.

The mathematics critical thinking ability test is done twice for each samples, namely pretest (initial test) and posttest (final test) with equivalent types of questions. As for the results of the pretest and posttest students' in mathematics critical thinking ability can be shown in the following table 2 and table 3 .

TABLE II. DESCRIPTION Mathematics CRitical Thinking PreteSt

\begin{tabular}{|c|c|c|c|c|c|c|}
\hline Sample & N & Min & Max & Mean & SD & Variance \\
\hline Experiment & 33 & 2 & 9 & 5,21 & 1,745 & 3,047 \\
\hline Control & 33 & 1 & 11 & 6,03 & 2,732 & 7,468 \\
\hline
\end{tabular}

Based on table 2, it can be seen that for the pretest minimun value in experimental class is greater than the control class but for the pretest maximum value in the experimental class is lower than the control class. As well as pretest mean scores, standard deviations and variances in the experimental class is lower than the control class.

TABLE III. Description Mathematics CRitical Thinking PostTEst

\begin{tabular}{|c|c|c|c|c|c|c|}
\hline Sample & N & Min & Max & Mean & SD & Variance \\
\hline Experiment & 33 & 10 & 16 & 12,97 & 1,468 & 2,155 \\
\hline Control & 33 & 8 & 15 & 12,61 & 2,061 & 4,246 \\
\hline
\end{tabular}

Based on table 3, it can be seen that for the posttest minimun value in experimental class is greater than the control class and for the posttest maximum value in the experimental class is greater than the control class. As well as posttest mean scores, standard deviations and variances in the experimental class is greater than the control class. From the table 2 and table 3 , these means that the pretest score and posttest score in the experimental class is less spread out than the pretest score and posttest score in the control class.

To see an increasing of students' mathematics critical thinking ability who taught by problem based learning and regular learning is to calculate the gain of both classes as the table 4 below:

TABLE IV. DATA OF INCREASING MATHEMATICS CRITICAL THINKING ABILITY

\begin{tabular}{|c|c|c|c|c|c|}
\hline \multirow{2}{*}{ Sample } & \multicolumn{5}{|c|}{ Data N-Gain Score } \\
\cline { 2 - 6 } & $\boldsymbol{X}_{\min }$ & $\boldsymbol{X}_{\max }$ & Mean & $\boldsymbol{S D}$ & Kategori \\
\hline Experimental & 0,40 & 1,00 & 0,723 & 0,134 & Sedang \\
\hline Control & 0,30 & 0,86 & 0,570 & 0,147 & Sedang \\
\hline
\end{tabular}

From table 4, can be seen that the minimum and maximum score in the experimental class is greater than the control class, it also for mean and standard deviation score in the experimental is greater than mean and standard deviation score in the control class. Its means that the N-Gain score for students' critical thinking ability in the experimental class is more spread out than students' critical thinking ability in the control class.

For the calculation of the two ways-Anava test N-Gain mathematics critical thinking ability in the experimental and control class are explained as follows:

The first hypothesis testing is done to test whether the increasing in mathematics critical thinking ability of students who are taught with problem based learning is higher than students who are taught with regular learning. The results obtained indicate that at a significant level of $5 \%$ the value of $\mathrm{F}$ for the learning factor (problem based learning and regular learning) is 12,621 with a significance value of 0.001 . Because the significant value is less than the significant level of $5 \%$, then $\mathrm{Ho}$ is rejected and $\mathrm{H} 1$ is accepted. Thus it can be concluded that the increasing in mathematics critical thinking ability of students who are given with problem based learning is higher than students who are given regular learning.

The second statistical hypothesis test is conducted to test whether there is an interaction between learning and students' prerequisite mathematics ability to increasing students' mathematics critical thinking ability. The results obtained indicate that at a significant level of $5 \%$ the value of $\mathrm{F}$ is 0.339 with a significance value of 0.714 . Because the significant value is greater than the significant level of 5\%, then $\mathrm{H} 1$ is rejected and $\mathrm{HO}$ is accepted. Thus it can be concluded that there is no significant interaction between learning and KAM on increasing students' mathematics critical thinking ability.

\section{B. Discussion}

One of the most influential factors on students' mathematics critical thinking ability is problem based learning. Problem based learning is carried out in five stages. One of the stages of problem-based learning that contributes greatly is the orientation of students to the problem, students are given worksheets that contain problems that have been designed to be solved. At this stage students are trained to think and work independently first in solving the problems given by the teacher. It is inversely proportional to normal learning where the teacher gives problems after the material is taught. Students are also not given test, only given routine questions contained in textbooks. This difference is considered to support the results of research that shows that problembased learning is effective for increasing students' mathematics critical thinking ability rather than regular learning.

\section{CONCLUSION}

Based on the results of research and discussion, obtained the following conclusions: (1) the increasing in mathematics critical thinking ability of students who are taught using 
problem-based learning is higher than the mathematics critical thinking ability of students who are given regular learning, (2) there is no interaction between learning and students' initial mathematical abilities to increase students' mathematical critical thinking skills. For this reason, it is suggested to be able to increasing students' mathematics critical thinking ability so it can be done by applying problem-based learning.

\section{REFERENCES}

[1] A. Syahbana, "Peningkatan Kemampuan Berpikir Kritis Matematis Siswa SMP Melalui Pendekatan Contextual Teaching and Learning." Edumatica, vol (02), nomor (01), 2012.

[2] I. A. Purnamasari, I. Pramudya, and I. Kurniawati, "Analisis Proses Berpikir Kritis Siswa dalam Pemecahan Soal Cerita Materi Persamaan Linear Satu Variabel yang Memuat Nilai Mutlak Ditinjau dari Minat Belajar Matematika Siswa Kelas X Semester II SMAN 1 Klaten Tahun Ajaran 2016/2017," Jurnal Pendidikan Matematika dan Matematika (JPMM) Solusi, Vol. 1, No. 2, p.57-73, 2017.
[3] Fachrurazi, Penerapan Pembelajaran Berbasis Masalah untuk Meningkatkan Kemampuan Berpikir Kritis Matematis dan Komunikasi Matematis Siswa Sekolah Dasar dan Menengah, Jakarta: Depdiknas, 2011.

[4] N. Karim, "Kemampuan Berpikir Kritis Siswa dalam Pembelajaran Matematika dengan Menggunakan Model Jucama di Sekolah Menengah Pertama", EDU-MAT Jurnal Pendidikan Matematika, Volume 3, No. 1, 2015.

[5] Wasriono, E. Syahputra, and E. Surya, "Pengembangan Perangkat Pembelajaran Berbantuan Autograph untuk Meningkatkan Pemahaman Konsep Matematik Siswa SMK Melalui Model Penemuan Terbimbing, “ Jurnal Paradikma, vol. 8,Nomor 3, p.52-61, 2015.

[6] R. Fristadi, and H.Bharata, "Meningkatkan Kemampuan Berpikir Kritis Siswa dengan Problem Based Learning", Seminar Nasional Matematika dan Pendidikan Matematika UNY, p. 597-602, 2015.

[7] Sunaryo, "Model Pembelajaran Berbasis Masalah untuk Meningkatkan Kemampuan Berpikir Kritis dan Kreatif Matematika Siswa SMA di Kota Tasikmalaya", Jurnal Pendidikan dan Keguruan, Vol. 1, No. 2, p. 41-51, 2014, Artikel 5. 